\title{
Analysis of the Potential of Solar Energy Development inSaudi Arabia
}

\author{
Fahad Alqahtani*, Hoda Sabeti**, and Majid Jaridi*** \\ *(Department of Industrial and Management Systems Engineering, West Virginia University Morgantown, West \\ Virginia, USA \\ ** (Department of Industrial and Management Systems Engineering, West Virginia University Morgantown, \\ West Virginia, USA \\ *** (Corresponding Author: Jaridi M, Department of Industrial and Management Systems Engineering, West \\ Virginia University, Morgantown, USA
}

\begin{abstract}
Saudi Arabia has been exploring the potential of renewable energy for many years. Saudi authorities, scientists, and researchers view the generation of renewable energy as a viable long-term energy strategy. Despite this, because Saudi Arabia is one of the leading oil producing nations and relies heavily on it as a form of energy and source of income, solar energy has not been given much serious consideration. However, it has become more and more evident that for the continuing prosperity of the nation and the inevitable gradual decline in long-term oil production, it is essential to explore and invest in alternative energy sources. The main objectives of this research are: i) to establish the potential of solar energy generation as a suitable, cost-effective alternative to petroleum products. ii) to establish the potential for maximizing renewable power generation to support the supply grid. This paper presents an examination of various economic and technological aspects of generating solar energy in Saudi Arabia. Using some existing data on the amount of solar radiation, a seasonal multiple linear forecasting method is used to generate forecasts for electric energy generation potential for 32 cities. Results of this research demonstrate the desirability and economic feasibility of installing solar panel farms and constructing distribution lines.
\end{abstract}

Keywords: Quantitative Forecasting, Renewable energy, Levelized Cost of Electricity (LCOE) generation model, Photovoltaic Generator

\section{INTRODUCTION}

Solar energy has been viewed by Saudi authorities, scientists, and researchers as a preferred this, the fact that Saudi Arabia is also one of the leading oil-producing nations and relies heavily on it as a form of energy, development, and distribution of electricity generated by solar power has not received serious consideration in the past. This research intends to examine the economic and technical aspect of solar energy development in Saudi Arabia and provides an approach to theanalysis of investments needed to achieve a successful gradual transition to solar energy.

\subsection{Problem Definition}

The main objectives of this research are to study the potential of solar energy generation as a suitable, cost-effective alternative to petroleum products and to develop a methodology to evaluate the potential for maximizing renewable power generation to support the supply grid to Saudi cities. Using irradiation data collected from government sources, we develop a forecasting model for the amount of solar energy that can be produced in 32 major cities of Saudi Arabia. The output of the forecasting model is then fed into an economic analysis model. The economic model employs estimates of the current cost of petroleum production, cost per unit production of solar energy and various other costs accrued during the production and distribution of the power generated using solar panels. This model can be used to identify regions in Saudi Arabia that have the most exposure to solar irradiation and can be considered as suitable solar energy production zones.

\subsection{Status ofNon-Renewable Energy inSaudi Arabia}

Saudi Arabia's oil reserve is one of the largest in the world, which has led to significant development in this segment of the country's economy. Heavy focus on petroleum has partly been motivated by the fact that oil sales are high and form a major component of the country's income. 
Statistics from 2010 indicate that income from oil made up about $90 \%$ of the country's total revenue. Saudi Arabia remains the largest exporter of petroleum-related products in the Middle East. Another major commodity is natural gas, for which Saudi Arabia was estimated to have the 4th largest reserves after Iran, Russia, and Qatar. Despite the rising interest and focus on renewable energy by consumers, research has shown that there is little motivation to explore and invest in alternative energy sources. The availability of non-renewable energy at a lower price places a barrier in the way of promoting renewable energy. High reliance on nonrenewable energy sources among consumers coupled with the production advantage has resulted in the domestic prices in Saudi Arabia for petroleum products, such as gasoline and natural gas, to be about $40 \%$ less than international prices.

\subsection{Status ofRenewable Energy inSaudi Arabia}

In Saudi Arabia, solar energy is the largest potential source of renewables. Despite the convergence of several factors that would seem to make solar power a viable source of energy, it remains largely unutilized or underutilized. The issue is not just the use of solar energy by the consumer, but also a significant lack of production capacity. Research shows that there is little investment in solar energy, especially by the state, in contrast to its heavy involvement and investment in petroleum products. This means that there is little motivation among state stakeholders, energy sector engineers, and other professionals in the sector to develop an effective policy that can be relied upon to push forward the widespread adoption of solar energy in Saudi Arabia.

The renewable energy issue in Saudi is further complicated by the high reliance among consumers on petroleum products. This is because of the current low cost of petroleum-based energy, as well as the high initial investment required to install solar energy production centers. It is worth noting that the average investment required for nonrenewable energy surpasses that of renewable energy, which means that high consumption plays a role in driving the growth of non-renewable energy at the expense of solar energy. In fact, the majority of existing solar power generating ventures are funded by the private sector where, given the current state of technology, the costs end up being high and unsustainable in the long run.

\section{LITERATURE REVIEW}

Renewable energy, and specifically solar energy, have been the subject of various studies with different approaches. In this section, we discuss previous works on the potential for generating renewable energy in Saudi Arabia, the issues with generating and distributing electricity from renewable sources and benefits associated with it.

Housing sector accounts for $52 \%$ of Saudi Arabia's total electricity consumption, and they propose Zero Energy Homes (ZEHs) as one of the ways in which the Saudi government can enhance sustainable housing practices in the country [1]. The study concluded that ZEHs do have the ability to withstand certain weather conditions, as well as the capability to produce energy that sustains and exceeds their consumption. Saudi Arabia has an immense wealth of solar exposure, having 2,200 thermal Kilowatts hours per square meter [2]. This article analyzes various projects that the country initiated and discusses the lessons learned from their operation and maintenance. The experience gained while applying quantitative assessment to the environmental benefits, costs, and savings that Saudi Arabia may receive from implementing large-scale solar energy projects [3]. Being in a location that is described as a sun belt, Saudi Arabia could become one of the largest producers of solar energy [4]. According to the article, photovoltaic cells can be used to generate clean solar energy, and there is a notable decrease in solar energy production cost making it economically viable compared to conventional fossil fuel.

The position of using photovoltaic power in the United States, China, and Japan. The study also seeks to discuss the subject countries' current and future policies regarding the use of such energy source. In a bid to promote the use of PV, European countries have introduced incentives for using PV panels. Germany and Spain lead in the use of PV as a percentage of their total energy production, while America holds the third position [5]. The lessons drawn from two Saudi Arabian solar projects, namely the Energy Research Institute (ERI) together with the King Abdulaziz Science and Technology City (KACST) [6]. They discuss activities such as PV, solar water heating, desalination, and solar hydrogen production, among others that were evaluated for solar energy applications. The paper notes that the main challenges in the deployment of solar energy include high cost as well as the lower conversion efficiency.

The determinants of the real cost of electricity are timing, location, and a few other characteristics. A controversy exists in the quantification of the non-market value of the reduced emissions since it is difficult to quantify; that is, the benefits that accrue from reduced emissions, e.g. a reduction in green gas emissions, cannot have a market value placed on them easily. Taxes on emissions, as well as a tradable permit system, represent some of the proposed marketbased policies [7]. 
On the role of renewable sources in the protection of the environment, Panwar, ET al. review the use of renewable technologies. They state that renewable energy mitigates both the effects of pollution and the effects of global warming [8]. Other article studies the commitment that various countries have made to renewable energy sources. They focus on 24 European countries while applying panel dynamic estimators. The paper also seeks to find the determinants that promote or hamper the implementation of the commitments and finds a positive relation between previous uses of renewable energy with the assessed period's usage. However, it lacks evidence that awareness plays a significant part in the use of renewable sources. They conclude that it was not the market that hampered the optimal use of renewable energy, but other sources were more influential mostly because of lack of stability in fossil fuel prices [9].

\section{METHODOLOGY \\ The methodology that was followed in this research is shown below.}

1. Data collection: Information on the average solar irradiation in 32 selected cities in Saudi Arabia was collected. Various data regarding the cost of solar panels and construction of solar farms, as well the cost of transmission were also be gathered.

2. Construct and analyze an appropriate forecasting model for modeling the seasonal pattern of the amount of irradiation in the selected cities.

3. Use of the output of the forecasting model as in input to an economic analysis model to determine the cost of generation and transmission of solar power in the selected cities.

The following subsections discuss these steps in detail.

\section{DATA COLLECTION}

This step included gathering the required data on the average solar irradiation in Saudi Arabia, the cost of solar panels, and other costs associated with the transmission of electricity from solar farms to consumer centers.

\subsection{Average Solar Irradiation in Saudi Arabia}

The amount of available solar irradiation varies across Saudi Arabia. Some regions of the country provide the highest potential in the world when it comes to solar energy production [10]. They study generated the map shown in Fig. 1 [10], indicating solar irradiation in different parts of Saudi Arabia.

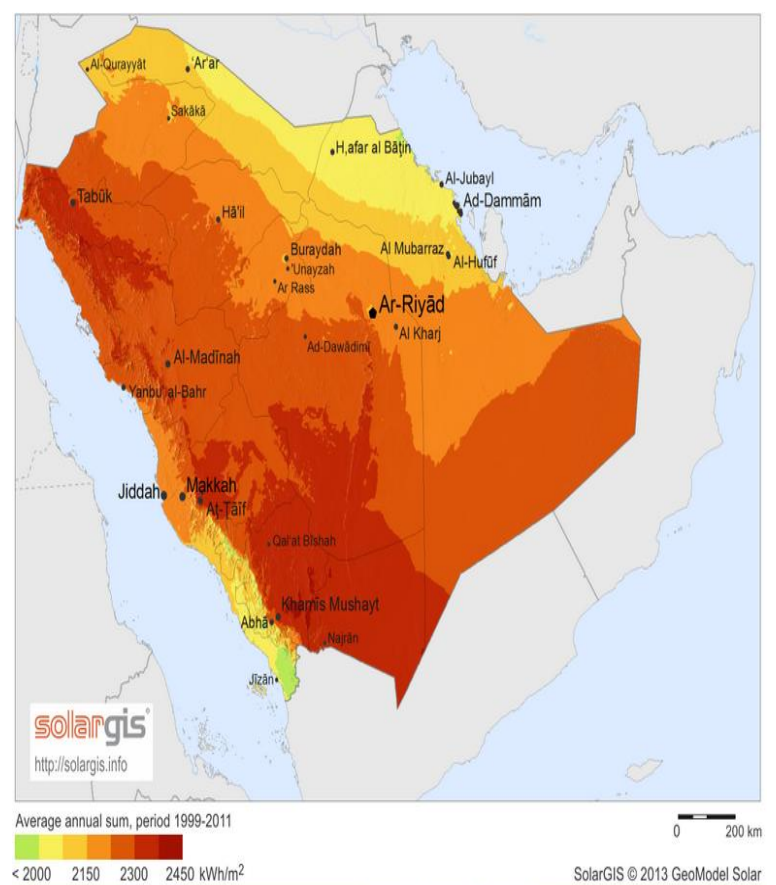

Fig. 1 Map Showing Solar Irradiation in Different Parts of Saudi Arabia [10]

From the map, it is clear that the regions of Tabuk, Hagl, and Taif receive the highest irradiation levels; hence, they are the best candidates for the installation of solar energy farms. TABLE 1 shows the average, maximum, and minimum direct normal irradiance for selected cities.

Table 1: Direct Normal Irradiance for Selected Cities [11]

\begin{tabular}{|l|c|c|c|}
\hline \multirow{2}{*}{ City } & \multicolumn{3}{|c|}{$\mathrm{kWh} / \mathrm{m}^{2} /$ day } \\
\cline { 2 - 4 } & Average & Maximum & $\begin{array}{c}\text { Minim } \\
\text { um }\end{array}$ \\
\hline Afif & 6.24 & 10.1 & 0.04 \\
\hline Al Aflaaj & 5.98 & 9.56 & 0.26 \\
\hline Al Baha & 7.54 & 10.21 & 1.01 \\
\hline $\begin{array}{l}\text { Al } \\
\text { Dawadmi }\end{array}$ & 6.12 & 10.39 & 0 \\
\hline $\begin{array}{l}\text { Al Hanakiyah } \\
\text { Hl }\end{array}$ & 6.36 & 10.99 & 0 \\
\hline Al Jouf & 5.17 & 7.99 & 0.22 \\
\hline $\begin{array}{l}\text { Al } \\
\text { Qunfudah }\end{array}$ & 4.53 & 8.19 & 0.02 \\
\hline $\begin{array}{l}\text { Al } \\
\text { Uyaynah }\end{array}$ & 5.76 & 10.34 & 0.01 \\
\hline Al Wajh & 6.71 & 10.3 & 0.07 \\
\hline Arar & 4.92 & 9.19 & 0.08 \\
\hline Duba & 7.06 & 10.66 & 0.03 \\
\hline $\begin{array}{l}\text { Hafar Al } \\
\text { Batin }\end{array}$ & 5.56 & 10.38 & 0 \\
\hline Jazan & 4.51 & 6.82 & 0.45 \\
\hline Riyadh & 5.97 & 10.27 & 0 \\
\hline Jeddah & 5.15 & 9.33 & 0.1 \\
\hline
\end{tabular}




\begin{tabular}{|l|c|c|c|}
\hline Thuwal & 5.46 & 9.6 & 0.01 \\
\hline Dammam & 5.44 & 10.08 & 0 \\
\hline Al Ahsa & 5.49 & 9.72 & 0 \\
\hline Majmah & 5.86 & 10.37 & 0 \\
\hline Najran & 6.59 & 10.37 & 0.01 \\
\hline Al Kharj & 5.55 & 9.2 & 0.02 \\
\hline Qassim & 6.1 & 10.27 & 0 \\
\hline Rania & 6.68 & 9.65 & 0.26 \\
\hline Yanbu & 5.65 & 8.52 & 0.5 \\
\hline Al Khafji & 4.81 & 8.4 & 0.19 \\
\hline Farrasan & 4.46 & 7.11 & 0.29 \\
\hline Hagl & 6.9 & 11.15 & 0 \\
\hline Umluj & 6.33 & 10.17 & 0 \\
\hline Al Jubail & 5.39 & 9.93 & 0 \\
\hline Shagra & 5.95 & 10.07 & 0.01 \\
\hline Tabuk & 7.09 & 11.27 & 0 \\
\hline Taif & 6.47 & 11.1 & 0.19 \\
\hline Timaa & 7.07 & 10.38 & 0 \\
\hline Wadi & 6.18 & 9.68 & 0.06 \\
\hline Addawasir & & & \\
\hline
\end{tabular}

Cost of Solar Panels

The cost of solar panels is marketdependent, and it reflects the level of consumption of solar power as a preferred choice of energy. A realistic estimate of the cost of solar panel installations per Watt of electricity generated. Figure 2 shows the decreasing trend of the price for crystalline Si panels from 1977 to 2013 [12].



Fig. 2 Solar Panels Costs (1977-2013) [12].

Using the estimates provided in this article, it is possible to determine the cost of solar panels required based on the projected Watt capacity targeted by a specific solar project. From the graph, it is evident that in 2013 the average cost was US $\$ 0.74$ per Watt of solar electricity generated.
The cost of installation of solar power systems has gone down dramatically since 2008, leading to increasing affordability and exponential growth across different countries. The data presented in Fig. 3 shows the average cost of solar power system installation between 2006 and 2014 in different developed nations [13].

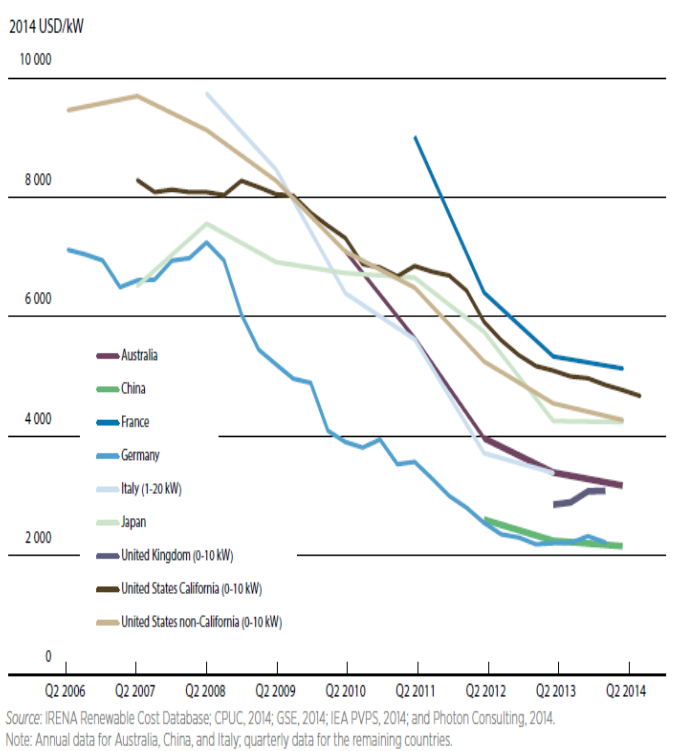

Fig. 3 Renewable Costs (2006-2014) [13].

\subsection{Number of Solar Panels for a Solar Panel Farm}

For a solar panel farm, solar panels are usually arranged in the form of parabolic trough collectors. This is the system that has already been installed in some solar panel farms in the Middle East region. TABLE 2 provides a breakdown of the associated civil and structural, solar field and their share in percentage for different components during solar energy production [13].

TABLE 2 Share in percentage for differentcomponents during solar energy production [13].

\begin{tabular}{|l|c|}
\hline \multicolumn{1}{|c|}{ Component } & Share (\%) \\
\hline Civil and Structural & 5 \\
\hline $\begin{array}{l}\text { Solar field preparation and } \\
\text { solar field work }\end{array}$ & 1 \\
\hline $\begin{array}{l}\text { Solar collector pylon } \\
\text { foundations }\end{array}$ & 2 \\
\hline $\begin{array}{l}\text { Power block and balance of } \\
\text { plant structures }\end{array}$ & 2 \\
\hline Solar Field & 64 \\
\hline $\begin{array}{l}\text { Health collector elements } \\
\text { (HCE) }\end{array}$ & 10 \\
\hline Reflectors & 14 \\
\hline Metal support structures & 20 \\
\hline
\end{tabular}




\begin{tabular}{|c|c|}
\hline $\begin{array}{l}\text { Drivers, electronic and } \\
\text { controls }\end{array}$ & 2 \\
\hline $\begin{array}{l}\text { Heat transfer fluid (HTF) } \\
\text { piping between collectors }\end{array}$ & 1 \\
\hline HTF header piping & 2 \\
\hline HTF fluid initial filling & 3 \\
\hline $\begin{array}{l}\text { Transport, erection, and } \\
\text { commissioning }\end{array}$ & 11 \\
\hline $\begin{array}{l}\text { Heat transfer fluid system, } \\
\text { including solar heat } \\
\text { exchangers }\end{array}$ & 9 \\
\hline $\begin{array}{l}\text { HTF heat exchangers and } \\
\text { tanks }\end{array}$ & 5 \\
\hline HTF pumps & 2 \\
\hline $\begin{array}{l}\text { Transport, erection, and } \\
\text { commissioning }\end{array}$ & 2 \\
\hline Power Block & 23 \\
\hline Steam turbine generators & 7 \\
\hline $\begin{array}{l}\text { Cooling system including } \\
\text { condenser }\end{array}$ & 7 \\
\hline $\begin{array}{l}\text { Fuel gas system including } \\
\text { backup }\end{array}$ & 1 \\
\hline Balance of plant & 0 \\
\hline Waste water treatment & 1 \\
\hline Fire protection & 4 \\
\hline Electrical and Installation & 2 \\
\hline $\begin{array}{l}\text { Transport, erection and } \\
\text { commissioning and other }\end{array}$ & 2 \\
\hline TOTAL & 100 \\
\hline
\end{tabular}

\subsection{Electricity Produced per Solar Panel}

The amount of electricity produced per solar panel depends on the peak solar irradiation time. During low irradiation times, the amount of electricity generated is not the same as during high irradiation times [14]. Consequently, a typical solar panel produces an average of $200 \mathrm{~W}$ per day, but this depends on the efficiency and the size of solar panel being used. Liorens adds that an array of 25 panels can produce five kWh [15]. However, Energy Australia places the output at $3.84-4 \mathrm{kWh}$, while the Office of the Renewable Energy Regulator in Australia provides a figure of $3.79 \mathrm{kWh}$ for Sydney [16]. This disagreement implies that it may not be possible to predict precisely the output that can be generated from a solar cell array. TABLE 3 provides an estimate of solar energy generated using solar panels in different parts of the world.
Table 3:Energy Production [14].

\begin{tabular}{|c|c|c|c|c|}
\hline & Unit & $\begin{array}{c}\text { Australia } \\
\text { 2007-08 }\end{array}$ & $\begin{array}{c}\text { OECD } \\
2008\end{array}$ & $\begin{array}{c}\text { World } \\
2007 \\
\end{array}$ \\
\hline \begin{tabular}{|l|} 
Primary \\
Energy \\
consumption
\end{tabular} & PJ & 6.9 & 189.4 & 401.8 \\
\hline Share of total & $\%$ & 0.12 & 0.09 & 0.08 \\
\hline $\begin{array}{l}\text { Average } \\
\text { annual } \\
\text { growth, from } \\
2000\end{array}$ & $\%$ & 7.2 & 4.3 & 9.6 \\
\hline \multicolumn{5}{|l|}{$\begin{array}{l}\text { Electricity } \\
\text { generation }\end{array}$} \\
\hline $\begin{array}{l}\text { Electricity } \\
\text { output }\end{array}$ & GWh & 0.1 & 8.2 & 4.8 \\
\hline Share of total & $\%$ & 0.04 & 0.08 & 0.02 \\
\hline $\begin{array}{l}\text { Average } \\
\text { annual } \\
\text { growth, from } \\
2000\end{array}$ & $\%$ & 26.1 & 36.3 & 30.8 \\
\hline $\begin{array}{l}\text { Electricity } \\
\text { Capacity }\end{array}$ & GW & 0.1 & 8.3 & 14.7 \\
\hline
\end{tabular}

\subsection{Cost of Transmission Lines}

The estimates provided in this section were retrieved from Wartsila, leading manufacturing and energy Installations Company in Finland, specifically looking at estimates provided for the year 2011. The cost of building a transmission line largely depends on the model adopted for transmission. In the case of a tunnel transmission system, there will be fixed and variable costs associated with tunnel and shaft construction, tunnel boring machine costs, and overheads. The cost of a transmission line depends on whether it is an overhead or underground system. For the overhead system, there are single, double, and multiple circuits, all of which affect the cost of transmission [17].

The cost of an underground system is significantly higher than the cost of an overhead system, mainly due to trenching costs. TABLE 4 compares the cost of these two transmission systems for different voltage lines [18].

Table 4Comparison of overhead and underground transmission costs [18]

\begin{tabular}{|l|c|c|}
\hline \multicolumn{1}{|c|}{ Type } & $\begin{array}{c}\text { Overhead } \\
\text { transmission }\end{array}$ & $\begin{array}{c}\text { Underground } \\
\text { transmission }\end{array}$ \\
\hline $\begin{array}{l}69 \mathrm{kV} \text { single } \\
\text { circuit } \\
\text { transmission line }\end{array}$ & $\begin{array}{c}\$ 285,000 \mathrm{per} \\
\text { mile }\end{array}$ & $\begin{array}{c}\$ 1.5 \text { million } \\
\text { per mile }\end{array}$ \\
\hline $\begin{array}{l}138 \mathrm{kV} \text { single } \\
\text { circuit } \\
\text { transmission line }\end{array}$ & $\begin{array}{c}\$ 390,000 \mathrm{per} \\
\text { mile }\end{array}$ & $\begin{array}{c}\$ 2.0 \text { million } \\
\text { per mile }\end{array}$ \\
\hline
\end{tabular}


Other substantive cost estimates for an overhead system, which would be the ideal choice in a solar energy transmission system [17]. According to these estimates, the costs for an overhead system will vary depending on the height of the tower. Juho adds that there are other costs associated with the civil construction process, such as earth excavation, earth filling, boxing work, concrete, iron fitting, land clearing costs (depending on the density of vegetation), engineering costs, and commissioning costs. Juho's illustration of the component costs for a typical transmission line can be seen in Fig. 4.



Fig. 4 Transmission cost estimate components for an $8 \mathrm{~km}$ transmission [17]

Fig. 5 shows the prices for different voltage models at a constant line length of $10 \mathrm{~km}$.

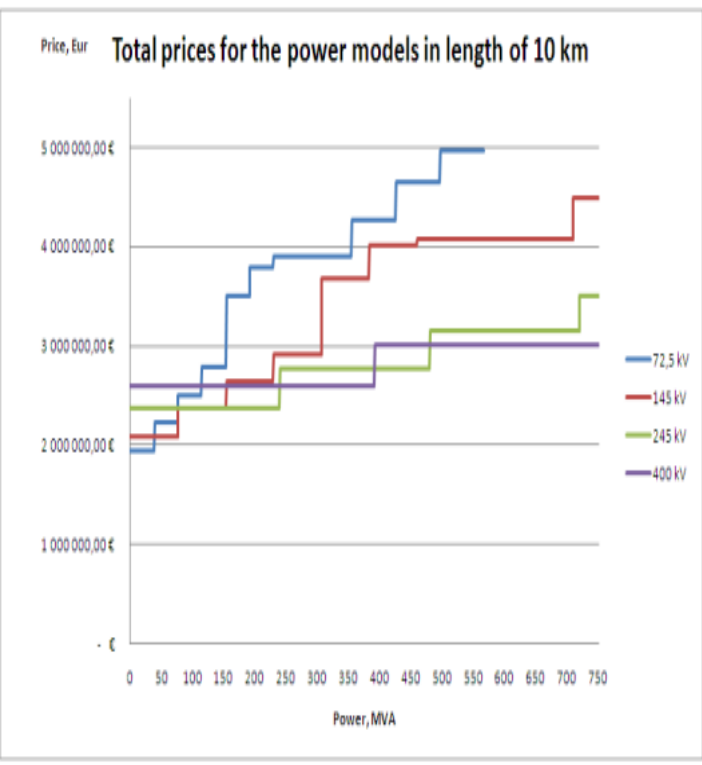

Fig. 5 Price for the Power Models [17]
Fig. 6 is an illustration of the cost per $\mathrm{km}$ and total costs for a $72.5 \mathrm{kV}$ and 0-38 MVA.

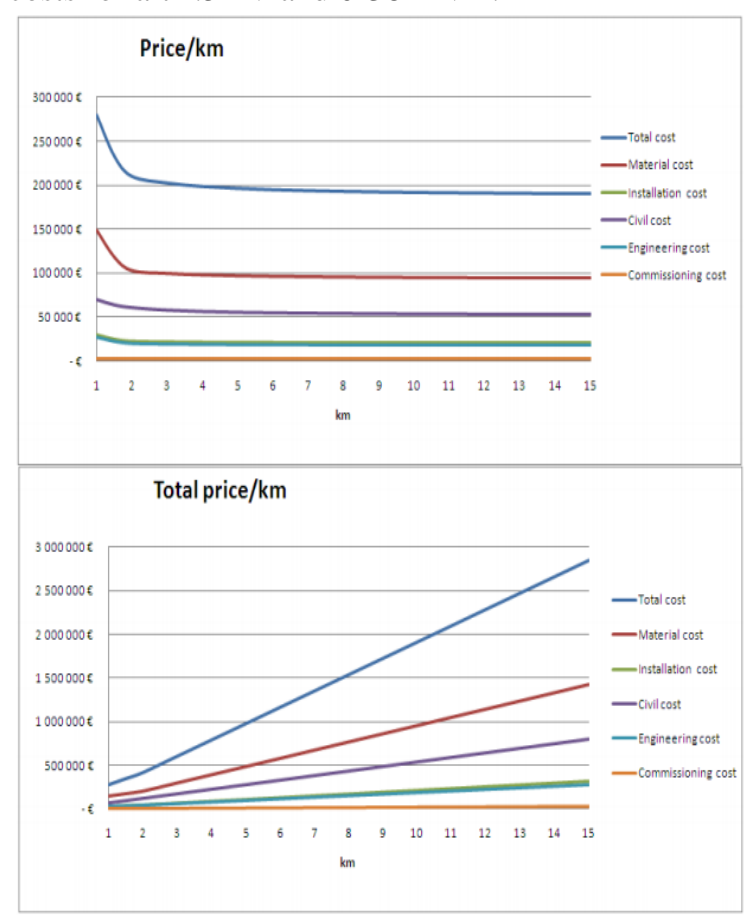

Fig. 6 Cost per Kilometer and Total Costs [17]

\subsection{Transfer of Electricity through Transmission Lines to Consumers}

The transfer of electricity through the transmission lines to consumers should be done by pursuing a model that lowers the civil, material, engineering, and commissioning costs associated with the transmission line. This should take into consideration the load, which is mostly determined by the number of consumers to be connected. It should also consider the uses for which the generated electricity will be used (e.g., residential or industrial), as each may have different demands from the system.

\subsection{Status of Renewable Energy in Saudi Arabia}

We use multiple linear regressions method of forecasting to predict the solar irradiation while considering the seasonality of the data. This approach analyzes a relationship between a dependent variable and several independent variables. To capture the seasonality of the irradiation data, sine and cosine functions have been included in the regression equation.

To illustrate the procedure for estimation of model parameters, we have used data from Tabuk City. The same process was then repeated for 31 other cities, and the regression coefficients for each city were estimated. We use the following linear regression model:

$$
x_{t}=b_{1}+b_{2} \operatorname{Sin} \frac{2 \pi t}{12}+b_{3} \operatorname{Cos} \frac{2 \pi t}{12}+\epsilon_{t}(1)
$$


In this research, the objective is to forecast the irradiation for next two years which requires 28 observations. The irradiation data for Tabuk City over 28 periods, as shown in TABLE 5 .

The least squares regression model estimate based on the data for Tabuk City was obtained as: $x_{t}=7.47614-2.7241 \operatorname{Sin} \frac{2 \pi t}{12}-2.406 \operatorname{Cos} \frac{2 \pi t}{12}+$ $\epsilon_{t}(2)$

Fig. 7 shows the actual data along with the forecast generated using equation 2 . It is obvious that the seasonal regression equation fits the actual data reasonably well.

Table 5 Irradiation data of Tabuk City [19]

\begin{tabular}{|c|c|}
\hline $\begin{array}{l}\text { Observation } \\
\text { Number }\end{array}$ & $\begin{array}{c}\text { Irradiation of Tabuk City } \\
\mathrm{kWh} / \mathrm{m}^{2} / \text { day }\end{array}$ \\
\hline 1 & 10.44 \\
\hline 2 & 9.65 \\
\hline 3 & 9.21 \\
\hline 4 & 8.76 \\
\hline 5 & 8.29 \\
\hline 6 & 7.61 \\
\hline 7 & 6.72 \\
\hline 8 & 5.82 \\
\hline 9 & 5.11 \\
\hline 10 & 4.26 \\
\hline 11 & 3.16 \\
\hline 12 & 1.36 \\
\hline 13 & 3.71 \\
\hline 14 & 4.82 \\
\hline 15 & 4.97 \\
\hline 16 & 5.08 \\
\hline 17 & 5.46 \\
\hline 18 & 6.63 \\
\hline 19 & 7.28 \\
\hline 20 & 8.84 \\
\hline 21 & 9.57 \\
\hline 22 & 10.44 \\
\hline 23 & 11.04 \\
\hline 24 & 11.27 \\
\hline 25 & 9.74 \\
\hline 26 & 7.15 \\
\hline 27 & 6.42 \\
\hline 28 & 5.84 \\
\hline
\end{tabular}

The same seasonal regression model was employed to generate a forecasting equation for the other 31 cities. Additionally, to gauge the accuracy of the forecast, we computed the Mean Squared Error (MSE) and Mean Absolute Percentage Error (MAPE) for each city using the following formulas:

$$
\begin{aligned}
M S E & =\frac{\sum_{t=1}^{T}\left(x_{t}-\widehat{x_{t}}\right)^{2}}{T-2} \\
\text { MAPE } & =\frac{1}{\mathrm{~T}} \sum_{\mathrm{t}=1}^{\mathrm{T}}\left|\frac{x_{t}-\widehat{x_{t}}}{x_{t}}\right| * 100(4)
\end{aligned}
$$



1335779111315171921232527

Month

$\underset{\hat{\mathrm{Y}}}{\text { Actual Data }}(\mathrm{Xt})$

Fig. 7 Actual and Forecast Data for Tabuk City [19]

TABLE 6 shows the fitted regression model for each city and their corresponding MSE and MAPE.

Table 6Seasonal Regression Equations, MSE, and

\begin{tabular}{|c|c|c|c|}
\hline City & Seasonal Regression Equation & MSE & MAPE \\
\hline Afif & $x_{t}=7.15-1.93 \operatorname{Sin} \frac{2 \pi t}{12}-1.77 \operatorname{Cos} \frac{2 \pi t}{12}+\epsilon_{t}$ & 47.21 & 659.70 \\
\hline Al Baha & $x_{t}=7.80-2.29 \operatorname{Sin} \frac{2 \pi t}{12}-2.60 \operatorname{Cos} \frac{2 \pi t}{12}+\epsilon_{t}$ & 55.29 & 778.40 \\
\hline Al Dawadmi & $x_{t}=6.839-2.453 \operatorname{Sin} \frac{2 \pi t}{12}-2.109 \operatorname{Cos} \frac{2 \pi t}{12}+\epsilon_{t}$ & 47.79 & 664.42 \\
\hline Al Hanakiyah & $x_{t}=6.933-2.329 \operatorname{Sin} \frac{2 \pi t}{12}-2.609 \operatorname{Cos} \frac{2 \pi t}{12}+\epsilon_{t}$ & 48.37 & 682.46 \\
\hline Al Qunfudah & $x_{t}=7.44-2.188 \operatorname{Sin} \frac{2 \pi t}{12}-1.953 \operatorname{Cos} \frac{2 \pi t}{12}+\epsilon_{t}$ & 43.27 & 542.63 \\
\hline Al Uyaynah & $x_{t}=7.356-2.745 \operatorname{Sin} \frac{2 \pi t}{12}-2.122 \operatorname{Cos} \frac{2 \pi t}{12}+\epsilon_{t}$ & 45.09 & 558.27 \\
\hline Al Wajh & $x_{t}=7.773-2.233 \operatorname{Sin} \frac{2 \pi t}{12}-2.920 \operatorname{Cos} \frac{2 \pi t}{12}+\epsilon_{t}$ & 50.54 & 748.75 \\
\hline Arar & $x_{t}=7.207-2.533 \operatorname{Sin} \frac{2 \pi t}{12}-1.844 \operatorname{Cos} \frac{2 \pi t}{12}+\epsilon_{t}$ & 28.23 & 436.00 \\
\hline Duba & $x_{t}=7.611-1.917 \operatorname{Sin} \frac{2 \pi t}{12}-2.806 \operatorname{Cos} \frac{2 \pi t}{12}+\epsilon_{t}$ & 26.38 & 421.53 \\
\hline Hafar & $x_{t}=7.866-2.295 \operatorname{Sin} \frac{2 \pi t}{12}-2.003 \operatorname{Cos} \frac{2 \pi t}{12}+\epsilon_{t}$ & 39.26 & 509.64 \\
\hline Jazan & $x_{t}=6.927-1.658 \operatorname{Sin} \frac{2 \pi t}{12}-1.937 \operatorname{Cos} \frac{2 \pi t}{12}+\epsilon_{t}$ & 37.64 & 487.21 \\
\hline Riyadh & $x_{t}=6.657-2.907 \operatorname{Sin} \frac{2 \pi t}{12}-2.635 \operatorname{Cos} \frac{2 \pi t}{12}+\epsilon_{t}$ & 38.58 & 492.72 \\
\hline Jeddah & $x_{t}=5.988-1.848 \operatorname{Sin} \frac{2 \pi t}{12}-1.609 \operatorname{Cos} \frac{2 \pi t}{12}+\epsilon_{t}$ & 43.73 & 549.81 \\
\hline Thuwal & $x_{t}=5.798-1.653 \operatorname{Sin} \frac{2 \pi t}{12}-1.740 \operatorname{Cos} \frac{2 \pi t}{12}+\epsilon_{t}$ & 42.92 & 525.01 \\
\hline Dammam & $x_{t}=7.625-2.193 \operatorname{Sin} \frac{2 \pi t}{12}-2.596 \operatorname{Cos} \frac{2 \pi t}{12}+\epsilon_{t}$ & 48.47 & 688.74 \\
\hline Al Ahsa & $x_{t}=5.681-1.397 \operatorname{Sin} \frac{2 \pi t}{12}-1.732 \operatorname{Cos} \frac{2 \pi t}{12}+\epsilon_{t}$ & 47.85 & 661.30 \\
\hline
\end{tabular}
MAPE for all cities 

ISSN: 2248-9622, Vol. 7, Issue 5, (Part-1) May 2017, pp.01-15

\begin{tabular}{|l|l|l|l|}
\hline Majmah & $x_{t}=6.781-2.482 \operatorname{Sin} \frac{2 \pi t}{12}-2.276 \operatorname{Cos} \frac{2 \pi t}{12}+\epsilon_{t}$ & 58.12 & 794.43 \\
\hline Najran & $x_{t}=6.506-2.093 \operatorname{Sin} \frac{2 \pi t}{12}-2.262 \operatorname{Cos} \frac{2 \pi t}{12}+\epsilon_{t}$ & 37.64 & 489.50 \\
\hline Al Kharj & $x_{t}=7.561-2.7321 \operatorname{Sin} \frac{2 \pi t}{12}-2.483 \operatorname{Cos} \frac{2 \pi t}{12}+\epsilon_{t}$ & 35.27 & 458.23 \\
\hline Qassim & $x_{t}=5.368-1.526 \operatorname{Sin} \frac{2 \pi t}{12}-1.164 \operatorname{Cos} \frac{2 \pi t}{12}+\epsilon_{t}$ & 31.38 & 447.01 \\
\hline Rania & $x_{t}=7.075-2.4101 \operatorname{Sin} \frac{2 \pi t}{12}-2.152 \operatorname{Cos} \frac{2 \pi t}{12}+\epsilon_{t}$ & 34.04 & 452.65 \\
\hline Yanbu & $x_{t}=6.651-2.091 \operatorname{Sin} \frac{2 \pi t}{12}-2.167 \operatorname{Cos} \frac{2 \pi t}{12}+\epsilon_{t}$ & 41.48 & 518.18 \\
\hline Al Khafji & $x_{t}=6.374-2.324 \operatorname{Sin} \frac{2 \pi t}{12}-1.946 \operatorname{Cos} \frac{2 \pi t}{12}+\epsilon_{t}$ & 45.80 & 559.70 \\
\hline Farrasan & $x_{t}=5.831-1.329 \operatorname{Sin} \frac{2 \pi t}{12}-1.402 \operatorname{Cos} \frac{2 \pi t}{12}+\epsilon_{t}$ & 39.24 & 506.14 \\
\hline Hagl & $x_{t}=5.840-1.732 \operatorname{Sin} \frac{2 \pi t}{12}-1.466 \operatorname{Cos} \frac{2 \pi t}{12}+\epsilon_{t}$ & 26.07 & 417.05 \\
\hline Umluj & $x_{t}=6.722-2.572 \operatorname{Sin} \frac{2 \pi t}{12}-2.171 \operatorname{Cos} \frac{2 \pi t}{12}+\epsilon_{t}$ & 29.37 & 442.71 \\
\hline Al Jubail & $x_{t}=7.320-2.143 \operatorname{Sin} \frac{2 \pi t}{12}-2.251 \operatorname{Cos} \frac{2 \pi t}{12}+\epsilon_{t}$ & 43.09 & 539.33 \\
\hline Shagra & $x_{t}=5.779-1.683 \operatorname{Sin} \frac{2 \pi t}{12}-1.458 \operatorname{Cos} \frac{2 \pi t}{12}+\epsilon_{t}$ & 44.56 & 548.09 \\
\hline Tabuk & $x_{t}=7.47-2.72 \operatorname{Sin} \frac{2 \pi t}{12}-2.416 \operatorname{Cos} \frac{2 \pi t}{12}+\epsilon_{t}$ & 23.02 & 389.46 \\
\hline Taif & $x_{t}=6.637-2.276 \operatorname{Sin} \frac{2 \pi t}{12}-2.126 \operatorname{Cos} \frac{2 \pi t}{12}+\epsilon_{t}$ & 48.09 & 676.01 \\
\hline Timaa & $x_{t}=7.267-2.398 \operatorname{Sin} \frac{2 \pi t}{12}-2.146 \operatorname{Cos} \frac{2 \pi t}{12}+\epsilon_{t}$ & 36.77 & 469.34 \\
\hline Wadi Addawasir & $x_{t}=5.577-1.832 \operatorname{Sin} \frac{2 \pi t}{12}-1.172 \operatorname{Cos} \frac{2 \pi t}{12}+\epsilon_{t}$ & 39.29 & 512.05 \\
\hline & & & \\
\hline
\end{tabular}

\subsection{Modeling of Photovoltaic Generator Cost}

It is important to understand what it costs to have a solar power system installed before any investment decision is made. Various models have been suggested to predict the cost of solar system installation. The most commonly used model is the Levelized Cost of Electricity (LCOE) generation model, which can be used to calculate the cost of installation of all renewable sources of energy [20]. The model makes use of the available information on solar radiation, ambient temperatures and manufacturer data for photovoltaic modules. Using this information and model input, the power output of the photovoltaic generator, $\mathrm{P}_{\mathrm{PV}}$ can be calculated using the following equation:

$$
P_{P V}=\eta_{g} N A_{m} G_{t},
$$

Where $\eta_{\mathrm{g}}$ represents the instantaneous PV generator efficiency, $\mathrm{A}_{\mathrm{m}}$ is the area of a single module in $\mathrm{m}^{2}, \mathrm{G}_{\mathrm{t}}$ is the global irradiance incident on the tilted plane in $\mathrm{W} / \mathrm{m}^{2}$ and $\mathrm{N}$ is the number of modules. The model assumes that there is zero loss of energy in the system. The instantaneous efficiency of the generator can be calculated using equation (6), below:

$\eta_{g}=\eta_{r} \eta_{p t}\left[1-\beta_{t}\left(T_{c}-T_{r}\right)\right](6)$

Where $\eta_{\mathrm{r}}$ is the reference efficiency of the PV generator, $\eta_{p t}$ is the efficiency of the power tracking equipment (which is equal to 1 if a perfect maximum power point tracker is used), $T_{c}$ is the temperature of the $\mathrm{PV}$ cell in Celsius, $\mathrm{T}_{\mathrm{r}}$ is the $\mathrm{PV}$ cell reference temperature and $\beta_{t}$ is the temperature coefficient of efficiency, ranging from 0.004 to 0.006 per ${ }^{\circ} \mathrm{C}$ for silicon cells. Based on the energy balance proposed by Duffie et al. (1991) [21], the $\mathrm{PV}$ cell temperature can be expressed as:

$$
T_{c}=T_{a}+G_{t}\left(\frac{\tau \alpha}{U_{L}}\right),
$$

Where $T_{a}$ is the ambient temperature in Celsius, $\mathrm{UL}$ is the overall heat loss coefficient in $\mathrm{W}$ per $\mathrm{m}^{2}$ per ${ }^{\circ} \mathrm{C}, \tau$ represents the transmittance coefficient of the PV cells, and $\alpha$ represents the absorption coefficient of PV cells. The overall heat loss coefficient $\left(\tau \alpha / \mathrm{U}_{\mathrm{L}}\right)$ can be estimated from the nominal operating cell temperature (NOCT) as follows [21]:

$\left(\frac{\tau \alpha}{\mathrm{U}_{\mathrm{L}}}\right)=\frac{\mathrm{NOCT}-20}{800}$

The instantaneous efficiency of the PV generator can, therefore, be expressed as follows:

$\eta_{g}=\eta_{r} \eta_{p t}\left\{1-\beta_{t}\left(T_{a}-T_{r}\right)-\beta_{t} G_{t}\left(\frac{N O C T-20}{800}\right)\left(1-\eta_{r} \eta_{p t}\right)\right\}$

The parameters $\eta_{\mathrm{pt}}, \beta_{\mathrm{t}}, \mathrm{NOCT}$, and $\mathrm{A}_{\mathrm{m}}$ depend on the type of module and are provided by the manufacturer.

\subsection{Estimation of the Number of Panels Needed in a Solar Power System}

When planning for the installation of a solar power system for residential or industrial use, it is important to have a reasonably accurate estimate of the number of solar panels needed to meet the demand. This can help in estimating the total cost that is likely to be incurred in assembling the system. The following formula can be used in estimating the number solar panels required for a solar system installation:

Number of solar panels $=$ solar radiation power $x$ surface area of panels in $\mathrm{m}^{2} \times$ efficiency $\times$ average days with sunshine per month (10)

An average of $4.5 \mathrm{kWh} / \mathrm{m}^{2} /$ day of solar radiation is commonly used in the United States. The values for every state are available on a map provided by the National Renewable Energy Laboratory (NREL) Resource Assessment Program. Most solar panels work at efficiencies of 7-17\%. To fully cover a monthly power usage of $1000 \mathrm{~kW}$, divide the figure obtained from equation (10) by 1,000 . 


\section{Estimation of the Cost of Solar Power}

Despite the improved efficiency offered by modern solar power systems, many people throughout the world do not know what it costs to install a solar power system in their homes and are reluctant to do so due to the uncertainties involved. Residential solar systems typically range in size from 3-8 $\mathrm{kW}$, which translates into a cost of between $\$ 15,000$ and $\$ 40,000$. In recent years, the cost per Watt, which includes the price of the parts of the system, labor costs, permitting fees, overhead costs, and profit, has been reduced significantly. The current cost per Watt stands at around \$6-8 per Watt in most parts of the US [20]. Solar power systems benefit significantly from economies of scale, meaning that larger systems translate into a lower cost per Watt. To find the total cost of a typical solar power system, one must consider all components such as the installation cost and operation and maintenance costs [22].

\section{a) The Cost of Solar Panels}

Solar panels usually account for approximately $30 \%$ of the total cost of a solar power system. A typical residential solar panel with a combined capacity of $3-8 \mathrm{~kW}$ costs between $\$ 4,000$ and $\$ 16,000$. It is important for solar power system users to know that the best solar panels are not necessarily the most expensive ones. The most reliable and most convenient way to rate the cost of solar panels is by considering their cost per Watt, the commonly accepted figure of merit. This is a reliable metric because it indicates the cost incurred in the acquisition of the solar panels as it relates to the power output. Due to widespread campaigns encouraging the use of renewable sources of energy, the cost of solar panels has been decreasing continually in recent years. Currently, the typical wholesale price of solar panels is well below $\$ 0.70 / \mathrm{W}$. For homeowners who buy small quantities at retail prices, this figure translates into approximately $\$ 1.50 / \mathrm{W}$ [22].

\section{b) Balance of System}

"Balance of system" refers to all the components of the solar system except for the panels themselves. The balance of system includes components such as inverters, of which there may be one or several, the mounts, the wiring system and other electrical components of the system. The balance of system represents approximately $20 \%$ of the total cost of the system. For homeowners, the expected cost of assembling the balance of system ranges from $\$ 3,000$ to $\$ 10,000$ [22].

\subsection{The Cost Model and Equations for Solar Systems}

The preferred cost model for renewable sources of energy, according to the International Renewable Energy Agency (IRENA), is the LCOE model. This model is based on a discounted cash flow (DCF) analysis to a common basis, taking into account the effect of time on the value of money [23]. The fact that most renewable sources of energy require a huge initial capital investment followed by almost zero operational cost means that the weighted average cost of capital (WACC), or the discounted rate used to evaluate the project, has a critical impact on the Levelized Cost of Electricity (LCOE) [20].The LCOE is defined mathematically as:

$$
\begin{aligned}
L C O E= & \frac{T P V \cdot C R F}{E_{\text {load }}}(11) \\
& \text { Where } \mathrm{E}_{\text {load }} \text { is the yearly output in } \mathrm{kWh} \text {, }
\end{aligned}
$$

TPV and CRF are the Total Present Value of the actual cost of all system components and the Capital Recovery Factor, respectively, which can be expressed as follows[24]:

CRF $=\frac{i(1+i)^{n}}{(1+i)^{n}-1}$

And

$\mathrm{TPV}=\mathrm{C}_{\mathrm{pv}}$

Where $\mathrm{i}$ is the annual discount rate, $\mathrm{n}$ is the system life in years, $\mathrm{C}_{\mathrm{pv}}$ is the sum of the present value of capital and maintenance costs of the PV generator in system life. The configuration with the lowest LCOE is taken as the optimal one from the set of configurations which guarantee the required LPSP (Loss of Power Supply Probability, an indicator of power system reliability).

There are many potential trade-offs that have to be taken into consideration when developing an LCOE modeling approach to the cost of renewable energy. First, the model is a simplistic approach because it needs to be applicable to a wider range of technologies in different countries and regions [20]. The analysis method is, however, transparent and easily understood. Also, more detailed LCOE analysis results in a significantly higher overhead regarding the many assumptions that have to be made. This means that the equations are, probably, more accurate [20].

The overall formula used for the calculation of the LCOE in $\$ / \mathrm{kWh}$ for renewable energy technology is [20]:

$$
L C O E=\frac{\sum_{t=1}^{n} \frac{I_{t}+M_{t}}{(1+r)^{t}}}{\sum_{t=1}^{n} \frac{E_{t}}{(1+r)^{t}}}
$$


Where LCOE is the average lifetime levelized cost of electricity generation, $I_{t}$ is the investment expenditure in year $t, M_{t}$ is the operation and maintenance expenditures in year $t, F_{t}$ is the amount in fuel expenditures in year $t, E_{t}$ is the electricity generation in year $\mathrm{t}, \mathrm{r}$ is the discount rate, and $\mathrm{n}$ is the economic life of the system in years.

\subsection{Applying the Cost Model to Tabuk City}

As a demonstration of how the cost model works, we will use the data for Tabuk City and show the steps for cost modeling in detail for a solar farm consisting of 12,729 solar panels.

TABLE 7, below, provides the nameplate generation capacity of solar panels given in units of GW for Tabuk City. The second item given in the table is the capacity factor, which is the ratio of a power plant's actual power output to its potential output if it were possibly operating consistently at full nameplate capacity. The total electricity generation capacity by the solar panel is $25.8 \mathrm{MW}$, the capacity factor is $16 \%$, and $36,161 \mathrm{GWh}$ are produced annually using solar panels.

Table 7Capacity, capacity factor, and generation for Tabuk City

\begin{tabular}{|l|c|c|}
\hline & Units & $\begin{array}{c}\text { Solar } \\
\text { Panels }\end{array}$ \\
\hline $\begin{array}{l}\text { Nameplate } \\
\text { Generation Capacity }\end{array}$ & MW & 25.8 \\
\hline Capacity Factor & $\%$ & 16 \\
\hline Annual Generation & GWh & 36,161 \\
\hline
\end{tabular}

Table 8 shows the capital cost calculations; it shows the capital cost rate, capital cost, capital cost for transmission and distribution additions, and the total capital cost for solar panels. The cost of capital describes the opportunity cost of making a particular investment. It is the rate of return that could have been earned by putting the same amount of money into a different investment with an equal amount of risk. In the same context, the capital cost of transmission and distribution refers to the opportunity cost of making the transmission and distribution of the solar panels.

table 8Capital Cost for Tabuk City

\begin{tabular}{|l|c|c|}
\hline \multicolumn{1}{|c|}{ Capital Cost } & Units & Solar Panels \\
\hline Capital Cost Rate & \$/kW & $\$ 4,650$ \\
\hline Capital Cost & \$Million & $\$ 120$ \\
\hline $\begin{array}{l}\text { Capital Cost for } \\
\text { Transmission \& } \\
\text { Distribution } \\
\text { Additions }\end{array}$ & \$Million & $\$ 95.12$ \\
\hline Total Capital Cost & \$Million & $\$ 215.12$ \\
\hline
\end{tabular}

Table 9 shows the LCOE, the cost of operating and building a generating plant for the period of an assumed financial life and duty cycle. This table provides the LCOE for both the system and technology in $\$ / \mathrm{MWh}$. It also shows the sum of the total cost of electricity for the transmission and distribution for solar panels and provides the total levelized cost in $\$ / M W h$. For the technology LCOE, $\$ 394 / \mathrm{MWh}$ is spent for solar panels, while $\$ 164$ /MWh is spent on the system LCOE. The LCOE for transmission \& distribution adds a total of $\$ 60 / \mathrm{MWh}$. Summing up the LCOE, a total of $\$ 225 / \mathrm{MWh}$ results.

Table 9 Levelized Cost of Electricity (LCOE)

\begin{tabular}{|l|c|}
\hline $\begin{array}{c}\text { Levelized Cost of } \\
\text { Electricity (LCOE ), } \\
\text { \$/MWh }\end{array}$ & Solar Panels \\
\hline Technology & $\$ 394$ \\
\hline System & $\$ 164$ \\
\hline $\begin{array}{l}\text { Transmission \& } \\
\text { Distribution Additions }\end{array}$ & $\$ 60.68$ \\
\hline Total & $\$ 224.68$ \\
\hline
\end{tabular}

TABLE 10 contains the total gross plant cost, total sent out plant cost, plant size, capacity factor, auxiliary load, thermal efficiency, fuel cost, $\mathrm{CO}_{2}$ transport and storage, fixed O\&M, variable O\&M, plant life in years, discount rate and capital recovery factor. Total gross plant cost is the amount paid for any owned asset. Plant size describes the physical dimensions of a plant. The auxiliary load is the device used to provide power for performing different functions. Fixed O\&M is the cost used for the operation and maintenance of the plant. Plant life describes the duration of which the plant can survive and function properly. The capital recovery factor is the ratio of a constant annuity to the current value of acquiring that annuity for a specific duration of time. TABLE 9 below shows that the total (gross and sent out) plant cost of solar panels is $\$ 4,650$. The sizes of the solar panels are $1 \times 5$ and $10 \times 5$. The capacity factor of the solar panels is $16 \%$. The auxiliary load is zero, which shows that neither uses any external device to provide power. The thermal efficiency, fuel cost, and $\mathrm{CO}_{2}$ transport and storage are not available. The capital recovery factor of the solar panels is 0.1070 .

Table 10 LCOE Inputs

\begin{tabular}{|l|c|c|}
\hline \multicolumn{1}{|c|}{ LCOE Inputs } & Units & $\begin{array}{c}\text { Solar } \\
\text { Panels }\end{array}$ \\
\hline $\begin{array}{l}\text { Total Plant Cost } \\
\text { (gross) }\end{array}$ & $\$ / \mathrm{kW}$ & 4,650 \\
\hline $\begin{array}{l}\text { Total Plant Cost (sent } \\
\text { out) }\end{array}$ & $\$ / \mathrm{kW}$ & 4,650 \\
\hline
\end{tabular}




\begin{tabular}{|l|c|c|}
\hline Plant Size (MW) & MW & $1 \times 5,10 \times 5$ \\
\hline Capacity Factor & $\%$ & 16 \\
\hline $\begin{array}{l}\text { Auxiliary Load } \\
\text { (HHV) }\end{array}$ & $\%$ & 0 \\
\hline Fuel Cost & \$/GJ & N/A \\
\hline $\begin{array}{l}\text { CO2 Transport and } \\
\text { Storage }\end{array}$ & N/A \\
\hline Fixed O\&M & \$/kW-yr. & $\$ 55$ \\
\hline Variable O\&M & \$MWh & 0 \\
\hline Plant Life & Years & 20 \\
\hline Discount Rate & $\%$ & 10.1 \\
\hline $\begin{array}{l}\text { Capital Recovery } \\
\text { Factor (CRF) }\end{array}$ & & 0.1070 \\
\hline
\end{tabular}

Table 11 shows the LCOE calculator for solar panels. It includes capital charges, fixed and variable O\&M costs, and fuel costs. Summing these all up, we can see that the solar panels require an investment of \$394/MWh.

Table 11LCOE Calculator

\begin{tabular}{|l|c|c|}
\hline $\begin{array}{c}\text { LCOE Calculator, } \\
\text { \$/MWh }\end{array}$ & Units & $\begin{array}{c}\text { Solar } \\
\text { Panels }\end{array}$ \\
\hline Capital Charges & $\$ / M W h$ & $\$ 355$ \\
\hline Fixed O\&M Cost & $\$ / M W h$ & $\$ 39$ \\
\hline Variable O\&M Cost & $\$ / M W h$ & $\$ 0$ \\
\hline $\begin{array}{l}\text { CO2 Transport and } \\
\text { Storage }\end{array}$ & $\$ / M W h$ & - \\
\hline Fuel Cost & $\$ / M W h$ & - \\
\hline LCOE & $\$ / M W h$ & $\$ 394$ \\
\hline
\end{tabular}

\section{RESULTS AND DISCUSSION}

The objectives of this research were:

i. Develop forecasting model for the amount of irradiation that can be produced in 32 major cities of Saudi Arabia so that can be input to the economic analysis model.

ii. Develop an economic analysis model to investigate the potential of solar energy as a cost-effective, suitable alternative to using petroleum products to generate power.

\subsection{Forecasting andSolar Power Model}

32 locations for solar stations were selected among all cities in Saudi Arabia. Details of the solar output of the selected locations are shown in TABLE 12 and depicted in Fig. 8. Also, model validation was done to assess the aptness of the forecasting models that were developed for each location. From the data collected for the demand at each city, the solar output and the number of required solar panels to meet the demand are shown for all 32 locations.

The model was run for different cities to report the output that can be generated from each location. Based on the model and the available data, users should be able to perform proper analysis to reach accurate conclusions. For example, in these results, Riyadh City has the highest amount of solar output at $32.22 \mathrm{GW}$, which represents $19.89 \%$ of the total output of all 32 locations. This is due to the ever increasing demand for energy from the population and businesses in the city, which contains 7 million people. In total, $20 \%$ of the country's total electricity consumption is due to the demand from Riyadh City.A large portion of Saudi Arabia's electricity consumption is from the housing sector [1].

From Fig. 8, it is clear that the regions of Tabuk, Arar, Taif, Riyadh, Dammam, and Jeddah receive the highest output of solar irradiation levels; hence, they are best suited for the installation of solar energy farm.

Table 12Summarized Solar Output in GW

\begin{tabular}{|l|c|c|}
\hline \multicolumn{1}{|c|}{ City } & $\begin{array}{c}\text { Solar Output } \\
\text { (GW) }\end{array}$ & $\begin{array}{c}\text { Number of } \\
\text { Solar } \\
\text { Panel }\end{array}$ \\
\hline Afif & 2.252 & 4,093 \\
\hline Al Ahsa & 22.910 & 17,484 \\
\hline Al Baha & 0.838 & 1,966 \\
\hline Al Dawadmi & 1.788 & 3,636 \\
\hline Al Hanakiyah & 1.467 & 3,257 \\
\hline Al Jubail & 0.970 & 2,426 \\
\hline Al Khafji & 0.870 & 1,984 \\
\hline Al Kharj & 2.108 & 3,983 \\
\hline Al Qunfudah & 0.483 & 1,527 \\
\hline Al Uyaynah & 0.862 & 1,972 \\
\hline Al Wajh & 0.705 & 1,851 \\
\hline Arar & 10.476 & 12,696 \\
\hline Dammam & 31.763 & 36,428 \\
\hline Duba & 0.750 & 1,897 \\
\hline Farrasan & 0.237 & 980 \\
\hline Hafar Al Batin & 1.463 & 3,238 \\
\hline Hagl & 1.809 & 3,751 \\
\hline Jazan & 0.824 & 1,907 \\
\hline Jeddah & 17.637 & 14,953 \\
\hline Majmah & 1.790 & 3,686 \\
\hline Najran & 1.987 & 3,832 \\
\hline Qassim & 2.955 & 4,981 \\
\hline Rania & 1.557 & 3,462 \\
\hline Riyadh & 32.228 & 39,519 \\
\hline Shagra & 1.038 & 2,522 \\
\hline Tabuk & 2.510 & 12,729 \\
\hline Taif & 0.382 & 4,546 \\
\hline Thuwal & 2.745 & 1,338 \\
\hline Timaa & 1.012 & 2,621 \\
\hline Umluj & 4,006 \\
\hline Wadi Addawasir & 2.243 & 1,995 \\
\hline Yanbu & & \\
\hline
\end{tabular}






Fig. 8 Summarized Solar Output in GW

Table 13 shows the percentage of the total output of solar for each city. Riyadh and Dammam City have the highest values which are $19.89 \%$ and $19.603 \%$, respectively.

Table 13 Percentage of Total output

\begin{tabular}{|l|c|}
\hline \multicolumn{1}{|c|}{ City } & $\begin{array}{c}\text { Percentage of Total } \\
\text { output \% }\end{array}$ \\
\hline Afif & 1.390 \\
\hline Al Ahsa & 14.139 \\
\hline Al Baha & 0.517 \\
\hline Al Dawadmi & 1.103 \\
\hline Al Hanakiyah & 0.905 \\
\hline Al Jubail & 0.599 \\
\hline Al Khafji & 0.537 \\
\hline Al Kharj & 1.301 \\
\hline Al Qunfudah & 0.298 \\
\hline Al Uyaynah & 0.532 \\
\hline Al Wajh & 0.435 \\
\hline Arar & 6.465 \\
\hline Dammam & 19.603 \\
\hline Duba & 0.463 \\
\hline Farrasan & 0.146 \\
\hline Hafar Al Batin & 0.903 \\
\hline Hagl & 1.117 \\
\hline Jazan & 0.508 \\
\hline Jeddah & 10.885 \\
\hline Majmah & 1.105 \\
\hline Najran & 1.226 \\
\hline & \\
\hline
\end{tabular}

\begin{tabular}{|l|c|}
\hline Qassim & 1.824 \\
\hline Rania & 0.961 \\
\hline Riyadh & 19.890 \\
\hline Shagra & 0.640 \\
\hline Tabuk & 6.486 \\
\hline Taif & 1.535 \\
\hline Thuwal & 0.239 \\
\hline Timaa & 1.694 \\
\hline Umluj & 0.624 \\
\hline Wadi Addawasir & 1.384 \\
\hline Yanbu & 0.544 \\
\hline
\end{tabular}

\subsection{LCOEANALYSIS}

TABLE 14 shows that the total cost of solar energy generation is $\$ 590.164 \mathrm{M} / \mathrm{MWh}$, which represents the cost of generating that power in each city. The highest cost was from Farrasan, with $\$ 90.775 \mathrm{M} / \mathrm{MWh}$, which represents $15 \%$ of the total cost. The locations with the lowest costs are Dammam and Riyadh City, which have $\$ 0.676$ $\mathrm{M} / \mathrm{MWh}$, and $\$ 0.667 \mathrm{M} / \mathrm{MWh}$, respectively.

TABLE14 Summarized LCOE for Each City

\begin{tabular}{|c|c|}
\hline City & LCOE (\$ M/MWh) \\
\hline Afif & 9.539 \\
\hline Al Ahsa & 0.938 \\
\hline Al Baha & 25.641 \\
\hline Al Dawadmi & 12.017 \\
\hline Al Hanakiyah & 14.648 \\
\hline Al Jubail & 22.142 \\
\hline Al Khafji & 24.696 \\
\hline Al Kharj & 10.191 \\
\hline Al Qunfudah & 44.480 \\
\hline Al Uyaynah & 24.924 \\
\hline Al Wajh & 30.485 \\
\hline Arar & 2.051 \\
\hline Dammam & 0.676 \\
\hline Duba & 28.648 \\
\hline Farrasan & 90.775 \\
\hline Hafar Al Batin & 14.684 \\
\hline Hagl & 11.874 \\
\hline Jazan & 26.082 \\
\hline Jeddah & 1.218 \\
\hline Majmah & 12.001 \\
\hline Najran & 10.813 \\
\hline
\end{tabular}




\begin{tabular}{|l|c|}
\hline Qassim & 7.270 \\
\hline Rania & 13.798 \\
\hline Riyadh & 0.667 \\
\hline Shagra & 20.702 \\
\hline Tabuk & 2.044 \\
\hline Taif & 8.637 \\
\hline Thuwal & 55.524 \\
\hline Timaa & 7.826 \\
\hline Umluj & 21.238 \\
\hline Wadi Addawasir & 9.577 \\
\hline Yanbu & 24.364 \\
\hline
\end{tabular}

TABLE 15 shows the annual electricity generation statistics for all 32 cities. According to these statistics, the total electricity generation by fuel is $45.1 \mathrm{GW}$. In total, the cost of producing that amount of power is $\$ 2,300 \mathrm{M} / \mathrm{MWh}$. Thus, the total cost of generating power by fuel represents just $25.6 \%$ of the total cost of generating power from solar panels. Using statistical analysis, it was demonstratedthat building new farms of solar panels and wind turbines further reduce generation expenses. This recommendation, if adopted, could result in significant cost savings for Saudi Arabia.

Table 15 Summarized Average Levelized Cost of Production (Fuel)

\begin{tabular}{|l|c|c|}
\hline Plant Name & $\begin{array}{c}\text { Fuel } \\
\text { Type }\end{array}$ & $\begin{array}{c}\text { Average } \\
\text { Levelized Cost } \\
\text { of Production } \\
\text { (\$M/MWh) }\end{array}$ \\
\hline Afif & Diesel & 62.6 \\
\hline Al Ahsa & NG & 58.7 \\
\hline Al Baha & Diesel & 58.5 \\
\hline Al Dawadmi & Diesel & 61.6 \\
\hline Al Hanakiyah & NG & 58.6 \\
\hline Al Jubail & NG & 59.2 \\
\hline Al Khafji & Crude & 64.9 \\
\hline Al Kharj & Crude & 68.8 \\
\hline Al Qunfudah & Diesel & \\
\hline Al Uyaynah & Diesel & 65 \\
\hline Al Wajh & Diesel & 67.7 \\
\hline Arar & Crude & 64.1 \\
\hline Dammam & Crude & 67.5 \\
\hline Duba & NG & 70.1 \\
\hline
\end{tabular}

\begin{tabular}{|l|c|c|}
\hline Farrasan & Diesel & 78 \\
\hline Hafar Al Batin & Diesel & 66 \\
\hline Hagl & NG & 64.7 \\
\hline Jazan & Diesel & 65.6 \\
\hline Jeddah & Diesel & 70.1 \\
\hline Majmah & Diesel & 69 \\
\hline Najran & NG & 73.9 \\
\hline Qassim & NG & 66.8 \\
\hline Rania & Diesel & 74.6 \\
\hline Riyadh & Diesel & 76.7 \\
\hline Shagra & Crude & 74.5 \\
\hline Tabuk & Diesel & 76.6 \\
\hline Taif & Diesel & 105 \\
\hline Thuwal & Diesel & 79.3 \\
\hline Timaa & Crude & 88.5 \\
\hline Umluj & Diesel & 93.1 \\
\hline Wadi Addawasir & Diesel & 85.2 \\
\hline Yanbu & Diesel & 101.9 \\
\hline
\end{tabular}

\section{CONCLUSION AND RECOMMENDATIONS FOR FUTURE WORK}

This research was aimed at applying economic and sensitivity analyses to solar energy generation as compared to the use of non-renewable energy sources in Saudi Arabia.

Economic and sensitivity analyses of data collected at King Abdullah City for Atomic and Renewable Energy showed thatamong the several forecasting models tested, itwas found that the best method was Multiple Linear Regression with Sine and Cosine terms. Therefore, these models were developed for all 32 cities so that they can be used to forecast solar irradiation in the future.

In the course of this research, a model was also applied to find the power output of the solar generator $\mathrm{P}_{\mathrm{pv}}$. Inputs to this model include: $\mathrm{A}_{\mathrm{m}}$, the area of a single module used in the system in $\mathrm{m}^{2}, \mathrm{G}_{t}$, the global irradiance incident on the tilted plane in $\mathrm{W} / \mathrm{m}^{2}$, and $\mathrm{N}$, the number of modules in the system. The result of that model was used to find the power generation output for all 32 cities. Riyadh City was found to have the largest amount of potential output. Hence, Riyadh City is the best candidate city for the construction of a solar farm.

Concentrating solar power technology utilizes focused sunlight. Concentrating solar power plants generate electric power by using mirrors to 
concentrate the sun's energy and convert it into hightemperature heat. That heat is then channeled through a conventional generator. The plants consist of two parts: one that collects solar energy and converts it to heat, and another that converts the heat energy to electricity. Concentrating solar power technology utilizes three alternative technological approaches: trough systems, power tower systems, and dish/engine systems.

The solar panel system is capable of storing enough energy to produce power 6 hours after the Sun had set by using thermal storage. Solar panel plants can potentially operate for 65 percent of the year without the need for a backup fuel source. Also, the plant will have a capability with up to 6 hours' worth of storage. However, in aggregate, it is sensitive. On cloudy or rainy days, the plant should have a storage capacity to compensate for the inability to produce energy on those days and, if needed, be able to generate power using diesel and natural gas as a back-up.

This study focused on forecasting solar irradiation monthly over a period of 20 years, the potential output of solar power, and the total cost of generating and transmitting that power in Saudi Arabia. Below are several recommendations for further research:

- Include additional analysis to study the potential for maximizing renewable power generation to support the grid supply from Saudi Arabia to other nations.

- Enhance the predictive capability of the forecasting equations by using hourly data of solar irradiation in the selected cities.

- Develop prediction intervals on forecasts obtained from the seasonal model so that an upper and a lower limit on the expected costs associated with each option studied may be developed.

\section{REFERENCES}

[1]. Alrashed, F. \&Asif, M. (2015). Analysis of critical climate-related factors for the application of Zero-energy homes in Saudi Arabia. Renewable and sustainable energy reviews, 41(January 2015), 1395-1403.

[2]. Alawaji, H.S. (2001). Evaluation of solar energy research and its applications in Saudi Arabia - 20 years of experience. Renewable and sustainable energy reviews, 5(1), 59-77.

[3]. Alnatheer, O. (2005). The potential contribution of renewable energy to electricity supply in Saudi Arabia. Energy Policy, 33(18), 2298-2312.

[4]. Almasoud, H.A. \& Gandayh, M.H. (2015).Future of solar energy in Saudi Arabia. Journal of King Saud University-Engineering sciences, 27(2), 153-157.
[5]. Dincer, F. (2010). The analysis of photovoltaic electricity generation status, potential and policies of the leading countries in solar energy. Renewable and sustainable energy reviews, 15(1), 713-720.

[6]. Huraib, S.F. et al. (1996). Lessons learned from solar energy projects in Saudi Arabia. Renewable Energy, 9(1-4).1144-1147.

[7]. Borenstein, S. (2012). The private and public economies of renewable electricity generation. The journal of economic perspectives. 26(1), 67-92.

[8]. Panwar, L.N. et al. (2011). Role of renewable energy sources in environmental protection: A review. Renewable and sustainable energy reviews, 15(3), 1513-1524.

[9]. Marques, C.A \& Fuinhas, A.J. (2011). Drivers promoting renewable energy: A dynamic panel approach. Renewable and sustainable energy reviews, 15(3), 1601-1608.

[10]. Pazheri, R.F. (2014). Solar power potential in Saudi Arabia. Journal of engineering research and applications, 4(9), 171-174. Retrieved from

http://www.ijera.com/papers/Vol4_issue9/Ver sion\%205/AD4905171174.pdf

[11]. King Abdullah City for Atomic and Renewable Energy. (K.A.CARE). Retrieved 2015, from https://www.kacare.gov.sa/en/Pages/default.a spx

[12]. Shahan, Z. (2014). Solar Panel Cost Trends 10 Charts. Retrieved from http://cleantechnica.com/2014/09/04/solarpanel-cost-trends-10-charts/

[13]. International Renewable Energy Agency (IRENA). (2015). Renewablepower generation costs in 2014. Innovation and Technology Centre. Bonn, Germany.

[14]. Geoscience Australia et al. (2013). Australian Energy Resource Assessment. Canberra: Commonwealth of Australia.

[15]. Liorens, D. (2012). How much electricity does a solar panel produce? Retrieved from http://www.solarpowerrocks.com/solarbasics/how-much-electricity-does-a-solarpanel-produce/

[16]. Solar Choice Staff. (2010). How much energy will my solar cells produce?

[17]. Solar Choice. Retrieved from http://www.solarchoice.net.au/blog/howmuch-energy-will-my-solar-cells-produce/

[18]. Juho, Y.H. (2011). The transmission line cost calculation. Vaasan Ammattikoskeakoulu Vasa Yerkeshhogskola University of Applied Sciences. Retrieved from https://www.theseus.fi/bitstream/handle/1002 
4/29401/Yli-

Hannuksela_Juho.pdf?sequence $=1$

[19]. Alonso, F. \& Greenwell, C. (2013). Underground vs. overhead: Power line installation cost comparison and mitigation. Retrieved from: http://www.elp.com/articles/powergrid_intern ational/print/volume-18/issue-

2/features/underground-vs-overhead-powerline-installation-cost-comparison-.html.

[20]. King Abdullah University of Science and Technology Industry Collaboration Program (KICP) (2009). Saudi Arabia solar energy manufacturing and technology assessment. Retrieved from http://www.kaust.edu.sa/assets/downloads/kic p-solar-energy-study.pdf

[21]. International Renewable Energy Agency (IRENA) (2012), Renewable energy technologies: cost analysis series. Wind Power. Vol. 5, Issues 5/5.

[22]. Duffie, J. A., \& Beckman, W. A. (1991). Solar engineering of thermal processes. Hoboken, NJ: Wiley.

[23]. Nielsen, et al. (2010), Economy of Wind Turbines (Vindmøllers Økonomi), EUDP, Denmark.

[24]. Blanco, M.I. (2009), The economics of wind energy, Renewable and Sustainable Energy Reviews, Elsevier, Vol. 13, Issues 6-7, pp. 1372-1382.

[25]. Athanasia A. Lazou, Anastassios D. Papatsoris. 2000. The economics of PV standalone residential households: A case study for various European and Mediterranean locations; Solar Energy Materials and Solar Cells. 62 411-427. 